\title{
Responses of Rod Bipolar Cells Isolated from the Rat Retina to the Glutamate Agonist 2-Amino-4-phosphonobutyric Acid (APB)
}

\author{
Masayuki Yamashita and Heinz Wässle \\ Max-Planck-Institut für Hirnforschung, D-6000 Frankfurt 71, Germany
}

Isolated rod bipolar cells were obtained by enzymatic (papain) and mechanical dissociation of the adult rat retina. Virtually all intact bipolar cells in the dissociates expressed protein kinase $\mathbf{C}$ (PKC) immunoreactivity, a selective marker for rod bipolar cells in the in vivo retina. Whole-cell recordings were performed using nystatin in the patch pipette to minimize washout of those cytoplasmic components necessary for the maintenance of ionic currents. At holding potentials of $-\mathbf{3 3} \mathrm{mV}$, a tonic inward current was observed. The glutamate agonist 2-amino-4-phosphonobutyrate (APB) reduced this current by closing ion channels. Under normal conditions, $\mathrm{Na}^{+}$appeared to be the main charge carrier. Both the internal and the external $\mathrm{Ca}^{2+}$ concentrations were found to exert a powerful influence on the APB-sensitive current. We conclude that the rod bipolar cell in situ is depolarized at light onset.

Bipolar cells of all vertebrate retinas show a physiological dichotomy: one class is depolarized (ON-cells), and the other is hyperpolarized (OFF-cells), by a light increment in the receptive field center (Werblin and Dowling, 1969; Kaneko, 1970; Toyoda, 1973; Nelson and Kolb, 1983). There is growing evidence that this is the result of the activation of different transmitter receptors in the bipolar ccll dendritic membrane. For OFFbipolar cells, the photoreceptor transmitter (which is very likely an excitatory amino acid; Cervetto and MacNichol, 1972; Murakami et al., 1972; Marc and Lam, 1981; Ayoub et al., 1989; Copenhagen and Jahr, 1989) probably opens nonspecific cation channels (Toyoda, 1973; Murakami et al., 1975; Slaughter and Miller, 1983a,b; Lasater et al., 1984; Bloomfield and Dowling, 1985; Attwell et al., 1987). The situation seems to be more complicated for ON-bipolar cells (Saito, 1987). Based on results with 2-amino-4-phosphonobutyrate (APB), it has been postulated that nonspecific cation channels are closed (Shiells et al., 1981; Slaughter and Miller, 1981, 1985; Bloomfield and Dowling, 1985). However, there is also evidence that the photoreceptor transmitter opens specific channels (e.g., a $\mathrm{K}^{+}$channel) in ON-bipolar cells (Saito et al., 1979, 1981; Kondo and Toyoda, 1980; Nawy and Copenhagen, 1987, 1990; Saito and Kujiraoka, 1982). Either mechanism would lead to hyperpolarization of

\footnotetext{
Received Aug. 24, 1990; revised Feb. 1, 1991; accepted Feb. 26, 1991.

We would like to thank Susanne Wallenstein for excellent technical assistance, Felicitas Boij for preparing the figures, and Irmgard Odenthal for typing the manuscript. We are grateful to A. Ishida and J. Bormann for helpful comments on the manuscript and to P. Martin for improving the English. M.Y. was supported by the Naito Foundation. J. Bormann helped with some of the experiments.

Correspondence should be addressed to Heinz Wässle, Max-Planck-Institut für Hirnforschung, Deutschordenstrasse 46, D-6000 Frankfurt 71, Germany.
}

Copyright (C) 1991 Society for Neuroscience $0270-6474 / 91 / 112372-11 \$ 03.00 / 0$
ON-bipolar cells. Because the photoreceptor transmitter is released in darkness and this release is reduced by light, ONbipolar cells are depolarized by a light spot, while OFF-bipolar cells are hyperpolarized.

The light responses of mammalian rod bipolar cells have been reported as depolarizing in rabbit retina (Dacheux and Raviola, 1986) and as hyperpolarizing in the cat (Kolb and Nelson, 1983). However, there are several lines of evidence (summarized by Müller et al., 1988; Daw et al., 1990; Massey, 1990) that suggest that rod bipolar cells of all mammals are depolarizing. Karschin and Wässle (1990) have studied glutamate and APB responses in dissociated rod bipolar cells of the rat retina using whole-cell patch-clamp techniques. Glutamate and APB caused similar effects; however, APB was more potent. In 93 out of 133 voltageclamped cells, current responses were found when APB was applied. In 88 of these 93 cells, APB produced a conductance increase, whereas in five cells APB produced a conductance decrease. However, the responses were unstable and fragile, and this prevented further characterization of the channels.

Recently, it was observed by Nawy and Jahr (1990b), during whole-cell recordings from slices of tiger salamander retina, that responses of depolarizing bipolar cells to APB were "washed out." They suggest that the loss of a second-messenger system required to maintain the APB-sensitive channel in an open state causes the decrease in responsiveness. This suggests that, in the much smaller mammalian rod bipolar cells, washout of glutamate responses might occur rather quickly and thus be the reason why Karschin and Wässle (1990) could not characterize these channels.

In the present study, dissociated rod bipolar cells of the adult rat retina were patch clamped using the nystatin method in order to prevent the washout of APB responses (Horn and Marty, 1988). Nystatin, an antibiotic, perforates the cell membrane under the electrode tip and creates channels permeable to monovalent ions such as $\mathrm{K}^{+}, \mathrm{Na}^{+}$, or $\mathrm{Cl}^{-}$, but impermeable for divalent ions (e.g., $\mathrm{Ca}^{2+}$ ). Washout from the cytoplasm of internal secondmessenger systems seems to be minimized by this method (Horn and Marty, 1988; Kurachi et al., 1989). The responses to APB of isolated rod bipolar cells were measured, and the channels sensitive to APB were studied. APB application caused a conductance decrease in the majority of cells tested. Calcium was found to exert a powerful influence onto the APB-gated channels. The effects of changing the internal or the external $\mathrm{Ca}^{2+}$ concentration were measured.

\section{Material and Methods}

Dissociation and identification of rod bipolar cells. Adult albino rals $(150-250 \mathrm{gm})$ of both sexes were etherized and killed by cervical dislocation, and the eyes were quickly enucleated. Bipolar cells were iso- 
lated from the dissected retinas by an enzymatic (papain) and mechanical dissociation procedure, details of which are described in Karschin and Wässle (1990). The dissociated cells were plated on glass coverslips coated with poly-L-lysine. Bipolar cells were identified, using Nomarski optics $(40 \times$ objective), by their characteristic shape. Virtually all the dissociated bipolar cells in control dishes expressed protein kinase $\mathrm{C}$ (PKC) immunoreactivity (Fig. 1), which identifies them as rod bipolars (Negishi et al., 1988; Greferath et al., 1990; Karschin and Wässle, 1990).

Electrophysiological recordings with the nystatin method. Recordings were made in a chamber $(200-\mu \mathrm{l} \mathrm{vol})$ on an inverted microscope with Nomarski optics (Zeiss IM 35, GER) at room temperature $\left(\approx 23^{\circ} \mathrm{C}\right)$. The bath solution was continuously perfused under gravity pressure at a rate of $1 \mathrm{ml} / \mathrm{min}$. The bath solution contained (in $\mathrm{mm}$ ) $137 \mathrm{NaCl}, 5$ $\mathrm{KCl}, 2.5 \mathrm{CaCl}_{2}, 1 \mathrm{MgCl}_{2}, 10$ HEPES- $\mathrm{NaOH}$, and 22.2 glucose, at $\mathrm{pH}$ 7.2 .

Patch pipettes were made from glass capillaries (GC 150-10, Clark, UK, or GB 150-8P, Science Products GmbH, GER) on a modified vertical electrode puller (model $700 \mathrm{C}$, David Kopf Instruments, USA). The patch pipette solution contained $149 \mathrm{mM} \mathrm{KCl}$ or $\mathrm{CsCl}$ and $10 \mathrm{~mm}$ HEPES-KOH, at $\mathrm{pH}$ 7.2. Nystatin (Sigma) was dissolved in methanol $(5 \mathrm{mg} / \mathrm{ml}$ ) by sonication and added to the pipette solution at a concentration of $200 \mu \mathrm{g} / \mathrm{ml}$. The nystatin-containing pipette solution was filtered with cellulose nitrate filter (pore size, $0.05 \mu \mathrm{m}$; Sartorius $\mathrm{GmbH}$, GER). Undissolved nystatin remained on the filter, and the final concentration of nystatin was lower than the above value. The nystatincontaining solution was freshly prepared just before the recording. The electrode resistance was 11-15 M 2 in the normal external bath solution.

The liquid junction potentials of the patch pipette were measured as described by Fenwick et al. (1982) and were $-3 \mathrm{mV}$ with respect to the bath solution both with $\mathrm{KCl}$ and with $\mathrm{CsCl}$ in the electrode. The holding potentials were corrected for junction potentials.

The electrode tip was positioned on the cell surface using a piezoelectric remote-controlled micromanipulator (Physik Instrumente, GER), and a gigaohm seal was made by gentle suction. The seal resistance was measured by $10-\mathrm{mV}$ voltage steps from $-60 \mathrm{mV}$ and was more than $10 \mathrm{G} \Omega$ just after the seal formation. Fast transient capacitive currents due to the pipette were canceled by the circuit of the EPC-7 amplifier used to record cell responses (List Electronic, GER). No suction was applied to the pipette after the initial seal formation. Approximately $2-$ 5 min after the seal formation, nystatin made the mcmbranc of cellattached patch electrically permeable without rupture resulting in the so-called "perforated patch" (Horn and Marty, 1988). Additional capacitive currents appeared in response to the $10-\mathrm{mV}$ steps, reflecting the capacitance of the cell. The series resistance of the pipette and the perforated patch membrane were roughly estimated from the peak amplitudes of these capacitive currents. The series resistance was 200-500 $\mathrm{M} \Omega$, but this is likely to be an overestimate, because the peak amplitudes of the capacitive currents were attenuated by the limited speed of the recording system (limited at $3 \mathrm{kHz}$ ). Assuming that the maximum series resistance was $200 \mathrm{M} \Omega$, the voltage error for $17 \mathrm{pA}$ (the mean value of the APB-sensitive tonic inward currents at $V_{H}=-33 \mathrm{mV}$ ) would be about $3 \mathrm{mV}$. The holding potentials were not corrected for this possible error. Voltage commands were applied from -60 to $+60 \mathrm{mV}$, and outward $\mathrm{K}$ ' currents were activated in the voltage range more positive than $-30 \mathrm{mV}$ when the pipettes contained $\mathrm{KCl}$ solution. When $\mathrm{CsCl}$ solution was used, the outward currents were not observed or could be observed only in the first trial of the voltage commands, and they soon disappeared. The cells were usually held at $V_{H}=-33 \mathrm{mV}$. Further details of the recording system and data acquisition are given in Karschin and Wässle (1990).

Drugs were dissolved in bath solution and applied from six-barreled pneumatic puffer pipettes. The tip diameter of each pipette was about $10 \mu \mathrm{m}$, and the pipettes were placed close $(\approx 50 \mu \mathrm{m})$ to the cell. Air pressure $(0.3-0.5$ bar) was applied under computer control. Without the pressure, bath solution continuously flowed into the pipettes by capillary attraction. This effect prevented the test solutions from leaking out. The concentrations of drugs will be given in the Results and refer to the concentrations in the barrels of the puffer pipette. The actual concentrations at the cell membrane are lower and not known.

In some experiments, low- $\mathrm{Na}^{+}$or low $-\mathrm{Cl}^{-}$solutions were applied to cells with the puffer pipette. In the low- $\mathrm{Na}^{+}$solution, $137 \mathrm{~mm} \mathrm{NaCl}$ of the normal bathing solution was replaced with equimolar choline-Cl or $\mathrm{LiCl}$. These solutions contained about $5 \mathrm{mM} \mathrm{Na}^{+}$by adjusting $\mathrm{pH}$ with $10 \mathrm{~mm}$ HEPES-NaOH. In the low- $\mathrm{Cl}^{-}$solution, $\left[\mathrm{Cl}^{-}\right]$was decreased to half of the bath solution by replacing $137 \mathrm{~mm} \mathrm{NaCl}$ with $75 \mathrm{~mm} \mathrm{Na}$ acetate and $62 \mathrm{~mm} \mathrm{NaCl}$.
DL-2-Amino-4-phosphonobutyric acid (APB), a calcium ionophorc (A23187), GABA, amiloride, and the protein kinase $\mathrm{C}$ inhibitor $\mathrm{H}-7$ were obtained from Sigma (USA). The protein kinase $\mathrm{C}$ activator phorbol dibutyrate (PDBu) was from SERVA (Heidelberg, GER). It was dissolved in ethanol as a stock solution (1 mM).

\section{Results}

Identification and electrophysiological recording of isolated rod bipolar cells

As a result of the dissociation procedure, most of the cells lost their characteristic appearance, and many round cell bodies lacking any processes were present in the dissociates (Fig. 1A). However, solitary, typical bipolar cclls appcared rather well preserved (Fig. $1 A, B$ ): their perikarya were oval- or bottle-shaped and had an average diameter of $5-8 \mu \mathrm{m}$. Short bundles of dendrites were found on one pole, and a single axon up to $70 \mu \mathrm{m}$ long emanated from the other pole. The axons, sometimes branched, terminated in lobular swellings. Every cell in the dissociates that was classified because of this characteristic shape as a bipolar cell showed PKC immunoreactivity. PKC in the intact retina labels a single class of bipolar cell, namely, the rod bipolar cell (Negishi et al., 1988; Greferath et al., 1990; Karschin and Wässle, 1990). On this basis, we conclude that all intact bipolar cells in the dissociates were rod bipolar cells.

After positioning and sealing the electrode onto the bipolar cell perikaryon, it took approximately $2-5 \mathrm{~min}$ for the patch under the electrode tip to be perforated by nystatin. The pores made by nystatin are mainly permeable to monovalent cations such as $\mathrm{Na}^{+}$and $\mathrm{K}^{+}$. The cquilibration of $\mathrm{Cl}^{-}$ions is retarded because the permeability ratio $P_{\text {anion }}: P_{\text {cation }}$ is only 0.1 (Marty and Finkelstein, 1975; Horn and Marty, 1988). In order to confirm the electrical and ionic permeability of the patch membrane, and to make sure that the patch was not simply broken, the diffusion of $\mathrm{Cl}^{-}$was monitored routinely by applying GABA, in a concentration of $20 \mu \mathrm{M}$, to the cells. GABA-induced chloride currents are rather robust and large. They have been reported in practically all bipolar cells dissociated from mammalian retinas (Karschin and Wässle, 1990; Suzuki et al., 1990; Yeh et al., 1990). Figure 2, $A$ and $B$, shows responses of an isolated rod bipolar cell, one (Fig. $2 A$ ) taken immediately after the patch was perforated ( 2 min after the gigaseal), and a second (Fig. $2 B$ ) recorded $2.5 \mathrm{~min}$ later. In the first record (Fig. $2 A$ ), GABA application induces a prominent outward current that is probably caused by an influx of $\mathrm{Cl}^{-}$ions from the bathing medium (high chloride) into the cell (low chloride). In the second record, 2.5 min later (Fig. $2 B$ ), chloride from the electrode has diffused into the cell, making the $\mathrm{Cl}^{-}$concentration inside the cell and in the bathing medium more equal. Application of GABA again opens $\mathrm{Cl}^{-}$channels, but $\mathrm{Cl}^{-}$is now driven out of the cell, the holding potential $\left(V_{H}=-33 \mathrm{mV}\right.$ ) being more negative than the $\mathrm{Cl}^{-}$reversal potential. As a result, GABA application induces an inward current in Figure $2 B$.

If the same experiment is performed with conventional patchclamp recordings, where the patch is broken, a quick exchange between the patch pipette and the cytosol occurs (Tachibana and Kaneko, 1987). The GABA-induced current in Figure $2 C$ was measured with the conventional method, only $15 \mathrm{sec}$ after the patch was broken. GABA application caused an inward current, indicating that the $\mathrm{Cl}^{-}$exchange had already happened (for further details, see Yamashita and Wässle, 1991).

The experiment with $\mathrm{G} \wedge \mathrm{B} \wedge$ demonstrates that nystatin and the perforated patch method can be used to record whole-cell currents from isolated bipolar cells. The relatively slow reversal 

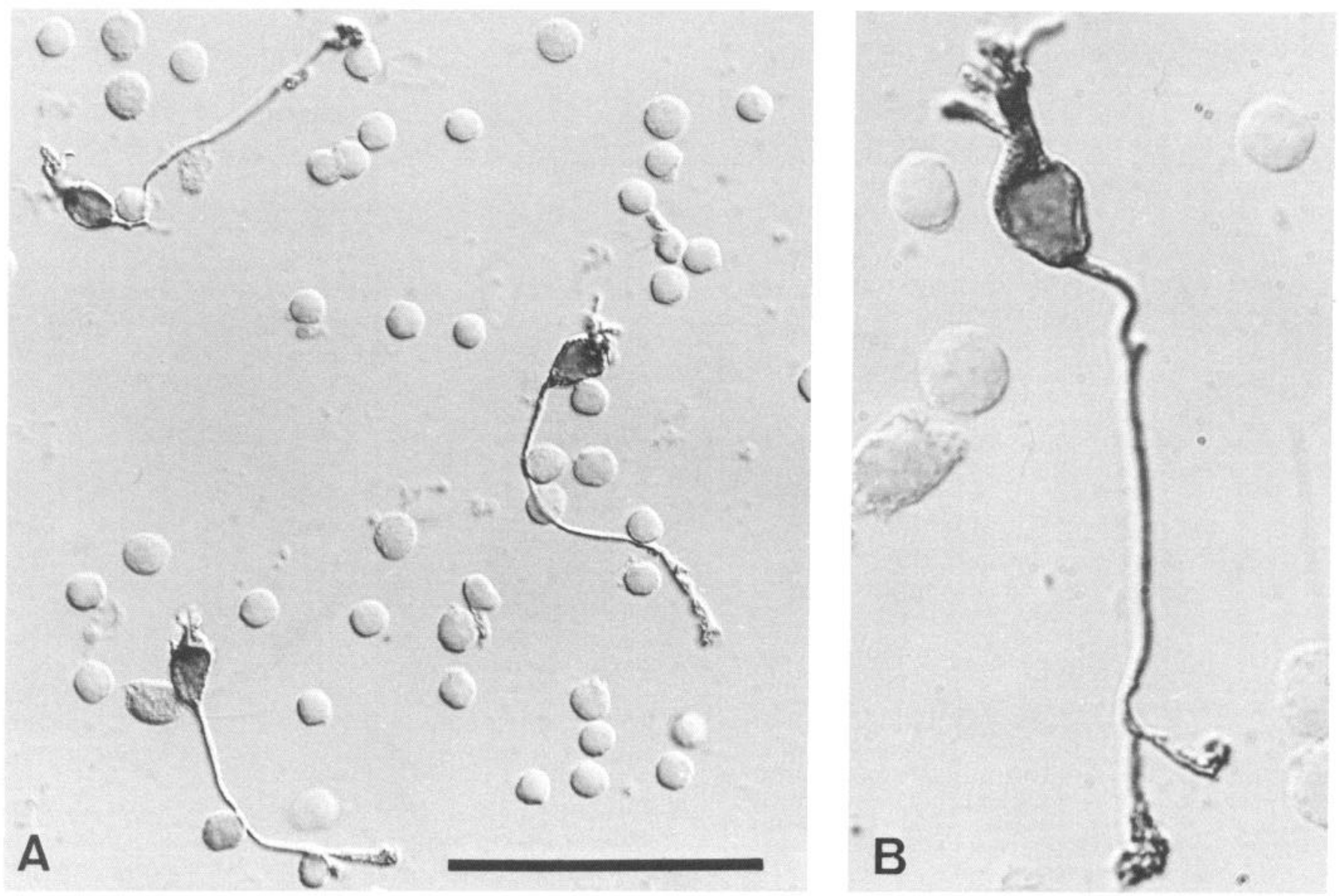

Figure 1. Cells dissociated from adult rat retina were stained with antibodies against PKC. All cells that have the characteristic appearance of bipolar cells are labeled (three cells in $A$, one in $B$ ). Many round cell bodies can also be detected in this Nomarski micrograph; they are retinal cells that have lost their processes during the dissociation procedure. In contrast, many bipolar cells seem to be rather well preserved; they are, on the basis of their immunoreactivity for PKC, identified as rod bipolar cells. Scale bar: $50 \mu \mathrm{m}$ for $A, 25 \mu \mathrm{m}$ for $B$.

of the current shows that the patch is not broken. Diffusion from the electrode through the nystatin pores can equilibrate the electrode solution and the cell interior within a few minutes. However, one has to keep in mind that the pore made by nystatin is permeable to monovalent cations and $\mathrm{Cl}^{-}$, while $\mathrm{Ca}^{2+}$ or second-messenger systems are not equilibrated (Horn and Marty, 1988).

\section{Responses of isolated rod bipolar cells to $A P B$}

In the present study, the membrane potential of rod bipolar cells was voltage clamped at $V_{H}=-33 \mathrm{mV}$. This value seemed within the physiological response range of bipolar cells and was just below the range where voltage-activated $\mathrm{K}^{+}$currents are evoked (Kaneko et al., 1989; Karschin and Wässle, 1990; Yeh et al., 1990). A more negative value of the holding potential was avoided, because at approximately $-60 \mathrm{mV}$ an inward rectifying current was reported in mammalian (Kaneko et al., 1989; Karschin and Wässle, 1990) as well as in nonmammalian bipolar cells (Kaneko and Tachibana, 1985; Lasater, 1988).

When the bipolar cell membrane was held at $V_{H}=-33 \mathrm{mV}$, tonic inward currents (exceeding $3 \mathrm{pA}$ ) were observed from 29 of 54 cells recorded. The mean amplitude of the tonic inward currents was $17 \mathrm{pA}$ (range, -4 to $-80 \mathrm{pA} ; \mathrm{SD}, 17.6 \mathrm{pA} ; n=$ 29). Leakage currents were not subtracted; with a seal resistance of more than $10 \mathrm{G} \Omega$, they might contribute up to $3 \mathrm{pA}$ to this tonic inward current. Such a current was present irrespective of whether $\mathrm{K}^{+}$or $\mathrm{Cs}^{+}$was used in the patch electrode. The current could not be blocked by $\mathrm{Mg}^{2+}$, which excludes the possibility that it is a sustained $\mathrm{Ca}^{2+}$ current. However, as discussed below, it was suppressed by choline. Figure $3, A$ and $C$, shows the effect of APB on this tonic inward current. When APB (puffer pipette concentration, 200 or $500 \mu \mathrm{M}$ ) was applied, the amplitude of the tonic inward current was decreased to approximately $20 \%$ of the predrug level. A comparable decrease of the tonic inward current by ejection of APB (200-500 $\mu \mathrm{M})$ was observed in 27 of the 29 cells. The mean amplitude reduction was to $59 \%$ (SD, $25.3 \% ; n=27$ ) of the predrug level. The APB effects were completely reversible. No slow desensitization was observed during the maximal application time of $7.5 \mathrm{sec}$, but a rapid desensitization cannot be ruled out. Rapid desensitization can only be revealed by a much more rapid application than is obtainable with the puffer pipette (Franke et al., 1987). Glutamate was found to produce similar effects, but was less potent than APB.

If APB causes closure of channels, then membrane resistance during APB application should be higher than without it, and APB should cause a reduction in noise. When the current traces of Figure 3, $A$ and $C$, were band-pass filtered $(5-500 \mathrm{~Hz})$, a reduction in noise was observed during application of APB (Fig. $3 B, D)$. Figure 4 shows a voltage ramp applied to a bipolar cell 
in the absence of APB and during APB application. The slope of the induced currents is decreased by the application of APB, indicating an APB-induced resistance increase.

Responses to APB were not observed in those 25 cells lacking the tonic inward current and only showing small leak currents.

\section{Ion selectivity of the APB-sensitive channel}

The ionic species carried by the APB-sensitive channel was examined by changing the holding potential and measuring the reversal potential of the tonic currents. For this purpose, we used $\mathrm{Cs}^{+}$-containing pipettes, in order to block the voltage-activated $\mathrm{K}^{+}$channels present in isolated rod bipolar cells (Kaneko et al., 1989; Karschin and Wässle, 1990; Yeh et al., 1990). When $\mathrm{K}^{+}$pipettes were used, outward rectification obscured the reversal potential of the APB-sensitive current.

Data of such a current/voltage measurement are presented in Figure 5. The cell recorded had a tonic inward current of $27 \mathrm{pA}$ at $V_{H}=-33 \mathrm{mV}$, which was reduced during APB application (not illustrated). The inset in Figure 5 (upper left) shows the currents when different holding potentials from $V_{H}=-33 \mathrm{mV}$ to $V_{n}=+33 \mathrm{mV}$ were applied. The current-voltage relation in the diagram was nearly ohmic in this voltage range, and the current reversed at about $-11.5 \mathrm{mV}$. Such experiments were made on seven cells, and the mean reversal potential was -10.8 $\mathrm{mV}$ (range, -3 to $-16 \mathrm{mV} ; \mathrm{SD}, 4.5 \mathrm{mV} ; n=7$ ). A reversal potential in this range excludes the possibility that this current is selectively carried by $\mathrm{Na}^{+}$or $\mathrm{Cs}^{+}\left(\mathrm{K}^{+}\right)$ions. It is compatible with a nonselective cation channel or $\mathrm{a} \mathrm{Cl}^{-}$channel.

The possibility of a nonselective cation channel was tested by changing the external solution to a low- $\mathrm{Na}^{+}$solution. $\mathrm{Na}^{+}$ions of the normal bathing solution were replaced by choline (see Materials and Methods), and this low- $\mathrm{Na}^{+}$solution was applied to the cell using a puffer pipette. Such nonselective cation channels are permeable to $\mathrm{Na}^{+}$, and to $\mathrm{K}^{+}$or $\mathrm{Cs}^{+}$(NMDA-gated channel: Ascher and Nowak, 1988; cGMP-gated channel: Yau and Nakatani, 1984a). At $V_{H}=-33 \mathrm{mV}$, a net inward current was measured; hence, $\mathrm{Na}^{+}$ions should be the major charge carrier. A reduction in the external $\mathrm{Na}^{+}$concentration should reduce the influx of $\mathrm{Na}^{+}$ions; it should not influence the efflux of $\mathrm{K}^{+}$or $\mathrm{Cs}^{+}$ions. The net inward current would be reduced or even change into an outward current carried by $\mathrm{K}^{+}$or $\mathrm{Cs}^{+}$ions.

Results from such an experiment are shown in Figure 6. In the following description, inward currents are expressed as negative and outward currents as positive in polarity. At $V_{H}=-33$ $\mathrm{mV}$, the cell of Figure $6 \mathrm{had}$ an APB-sensitive inward current of $-18 \mathrm{pA}$ in normal external solution. The inward current was greatly reduced by lowering external $\left[\mathrm{Na}^{+}\right]$, and eventually an outward current of $+1.3 \mathrm{pA}$ appeared. Such reversals were observed in four out of five cells tested. In normal solution, the four cells had a mean current of $-8.2 \pm 5.7 \mathrm{pA}$, which was reversed to $+1.9 \pm 0.5 \mathrm{pA}$. In the remaining cell, only a reduction of the inward current from -25.3 to $-6.1 \mathrm{pA}$ was observed. Perhaps the external solution around the cell was not completely exchanged. No difference was found in these experiments between using $\mathrm{Cs}^{+}$or $\mathrm{K}^{+}$in the recording pipettes. $\mathrm{A}$ similar experiment was performed in five cells, where low external $\mathrm{Cl}^{-}$solution was applied to the cells with a puffer pipette. This did not affect the tonic inward currents. However, the same low- $\mathrm{Cl}^{-}$solution increased GABA-induced inward currents as a control.

In summary, we conclude that the APB-sensitive channel is a nonselective cation channel permeable to $\mathrm{Na}^{+}, \mathrm{K}^{+}$, and $\mathrm{Cs}^{+}$

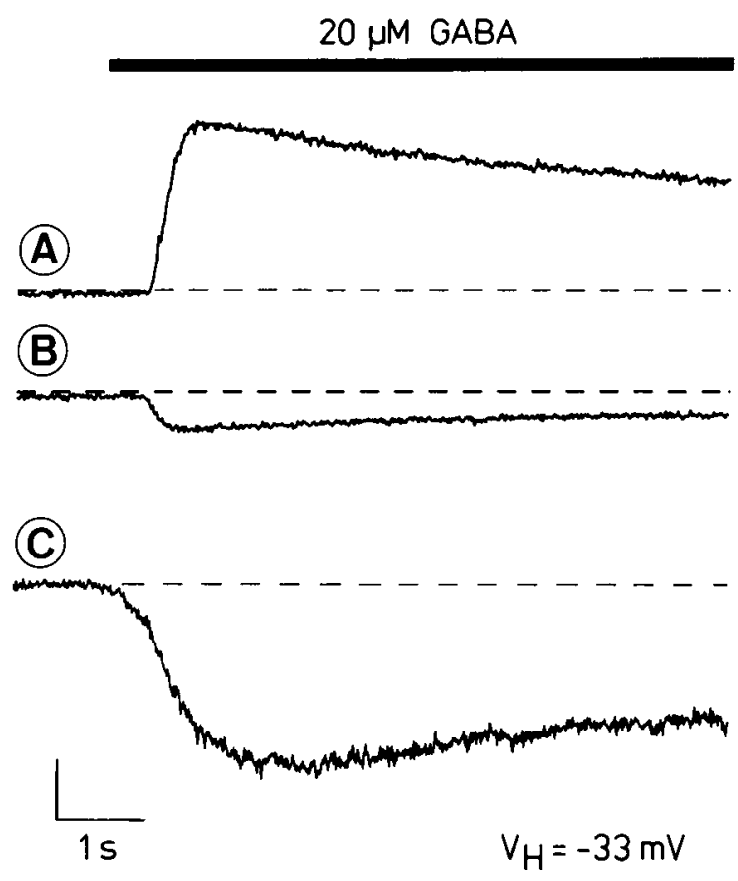

Figure 2. Whole-cell responses of isolated rod bipolar cells to GABA. The cells were voltage clamped at $V_{H}=-33 \mathrm{mV}$. Upward deflections, outward currents; downward, inward currents; broken lines, 0 current; horizontal bar, duration of GABA application. Vertical calibration: 10 pA for $A$ and $B, 100 \mathrm{pA}$ for $C$. $A$ and $B$ show recordings of the same bipolar cell with a nystatin-containing electrode. $A$, Response to GABA, approximately $2 \mathrm{~min}$ after the formation of the gigaseal. $B$, Response to GABA $2.5 \mathrm{~min}$ after the record in $A$ was taken. $C$, Responses to GABA of another bipolar cell during conventional patch-clamp recordings, $15 \mathrm{sec}$ after the patch was broken. The electrode in $A$ and $B$ contained $149 \mathrm{~mm} \mathrm{CsCl}, 10 \mathrm{~mm}$ HEPES-KOH at $\mathrm{pH} 7.2$, and nystatin $(200 \mu \mathrm{g} / \mathrm{ml}$ ); the bath solution contained (in $\mathrm{mm}$ ) $137 \mathrm{NaCl}, 5 \mathrm{KCl}, 2.5$ $\mathrm{CaCl}_{2}, 1 \mathrm{MgCl}_{2}, 10 \mathrm{HEPES}-\mathrm{NaOH}$, and 22.2 glucose, at $\mathrm{pH} 7.2$. The GABA concentration in the puffer pipette was $20 \mu \mathrm{M}$. The solutions in $C$ were identical, except that nystatin was not added to the electrode solution.

ions. Most of the inward current is carried by $\mathrm{Na}^{+}$ions under normal conditions.

\section{Modulation of APB-sensitive inward current by external $\mathrm{Ca}^{2+}$}

It has been reported that nonselective cation channels are blocked by extracellular $\mathrm{Ca}^{2+}$ in rod outer segments (Haynes et al., 1986) and frog muscle membranes (Almers et al., 1984). In the case of the NMDA receptor channels, $\mathrm{Ca}^{2+}$ acts as both a blocker and a permeator (Mayer and Westbrook, 1987; Ascher and Nowak, 1988). For this reason, we studied the influence of the extracellular $\mathrm{Ca}^{2+}$ concentration on the APB-gated inward current in rod bipolar cells.

Figure $7 A$ shows the effect of lowering the external $\mathrm{Ca}^{2+}$ concentration on the APB responses. One barrel of the puffer pipette was filled with APB $(500 \mu \mathrm{M})$ dissolved in the bath solution, where $\mathrm{Ca}^{2+}$ was replaced by equimolar $\mathrm{Mg}^{2+}$ (nominally $\mathrm{Ca}^{2+}$ free, no EGTA added). A second barrel was filled with APB $(500 \mu \mathrm{M})$ dissolved in normal bathing solution $\left(\mathrm{Ca}^{2+}\right.$ concentration, $2.5 \mathrm{~mm}$ ). When APB in $2.5 \mathrm{~mm} \mathrm{Ca}^{2+}$ was applied, the wellknown channel-closure effect was observed. However, when APB in low $\mathrm{Ca}^{2+}$ was applied, the tonic inward current was increased. Such reversals of the APB action by lowering the external $\mathrm{Ca}^{2+}$ concentration were observed in all four cells tested. The physiological concentration of extracellular $\mathrm{Ca}^{2+}$ has been suggested 
(A) $200 \mu \mathrm{M}$ APB

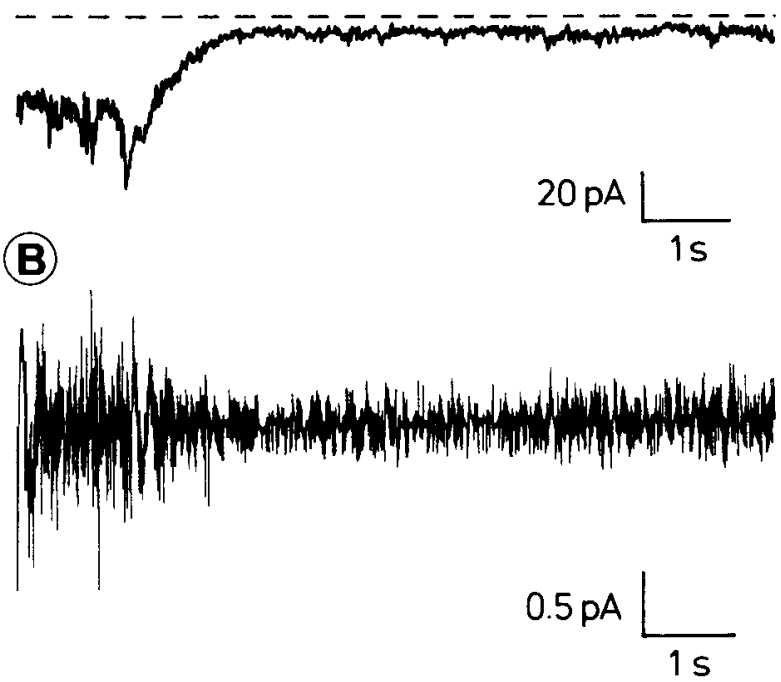

(C) $500 \mu \mathrm{M}$ APB

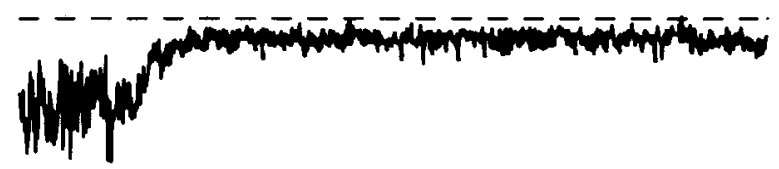

(D)
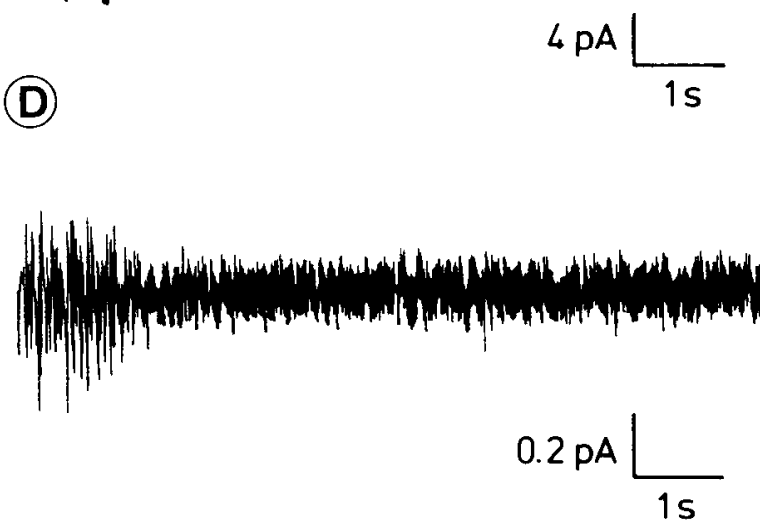

Figure 3. A, Whole-cell responses of an isolated bipolar cell of the rat retina during application of APB. The cell was voltage clamped at $V_{H}=$ $-33 \mathrm{mV}$, and a tonic inward current of approximately $30 \mathrm{pA}$ was observed. During application of APB (200 $\mu \mathrm{M})$, this current was reduced. $B$, Same recording as in $A$, but band-pass filtered $(5-500 \mathrm{~Hz})$ to illustrate the noise reduction by APB. $C$, Whole-cell responses of another rod bipolar cell, which had only a small inward current. APB application $(500 \mu \mathrm{M})$ reduced this current and, as illustrated in the band-pass-filtered record $(D)$, also caused a noise reduction. Broken lines, 0 currents; horizontal bars, APB application. The bath solution was (in mM) $137 \mathrm{NaCl}, 5 \mathrm{KCl}, 2.5$ $\mathrm{CaCl}_{2}, 1 \mathrm{MgCl}_{2}, 22.2$ glucose, and $10 \mathrm{HEPES}-\mathrm{NaOH}, \mathrm{pH} 7.2$. The electrode in $A$ and $B$ contained $149 \mathrm{mM} \mathrm{KCl}, 10 \mathrm{mM} \mathrm{HEPES}-\mathrm{KOH}$ at $\mathrm{pH} 7.2$, and nystatin $(200 \mu \mathrm{g} / \mathrm{ml})$; the electrode in $C$ and $D$ was filled with $149 \mathrm{~mm} \mathrm{CsCl}, 10 \mathrm{~mm} \mathrm{HEPES}-\mathrm{KOH}$ at $\mathrm{pH} 7.2$, and nystatin $(200 \mu \mathrm{g} / \mathrm{ml})$.

to be in the range of $2 \mathrm{~mm}$ in the isolated turtle retina (Perlman et al., 1990). At least this concentration seems to be necessary for APB to close the channel.

Prolonged application of low $\mathrm{Ca}^{2+}$ caused a slow increase of the tonic inward current, which could no longer be modulated by application of APB. It is possible that removal of $\mathrm{Ca}^{2+}$ from the bathing medium alters the gating properties of voltage-de-

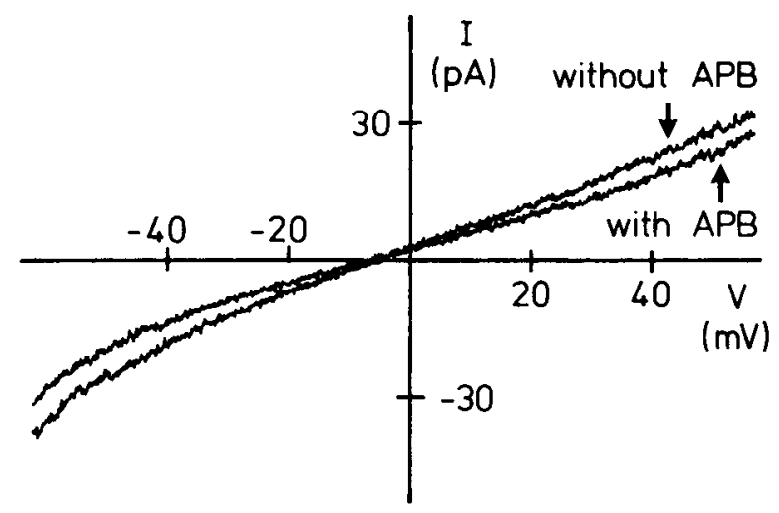

Figure 4. Current-voltage relations of an isolated bipolar cell with $(500 \mu \mathrm{M})$ and without APB application. A voltage ramp of $62 \mathrm{mV} / \mathrm{sec}$ was applied, and the whole-cell currents were measured. The deviation from linearity at potentials more negative than $-40 \mathrm{mV}$ probably represents the inward rectifying current (Karschin and Wässle, 1990). The patch pipette contained $149 \mathrm{~mm} \mathrm{CsCl,} 10 \mathrm{~mm}$ HEPES-KOH at pH 7.2, and nystatin $(200 \mu \mathrm{g} / \mathrm{ml})$; the bath solution contained (in $\mathrm{mM}) 137 \mathrm{NaCl}$, $5 \mathrm{KCl}, 2.5 \mathrm{CaCl}_{2}, 1 \mathrm{MgCl}_{2}, 22.2$ glucose, and 10 HEPES-NaOH, $\mathrm{pH}$ 7.2 . pendent $\mathrm{K}^{+}$channels and induces a large nonselective "leak" conductance (Armstrong and Miller, 1990).

The effect of high external $\mathrm{Ca}^{2+}$ concentration was also examined (Fig. $7 B$ ). One barrel of the puffer pipette was filled with the bath solution containing $25 \mathrm{mM} \mathrm{Ca}^{2+}$, and the other barrel with normal bath solution containing $500 \mu \mathrm{M}$ APB. The inward current in Figure $7 B$ was reduced by the application of high $\mathrm{Ca}^{2+}$ even in the absence of APB. It was also reduced by APB in normal $\mathrm{Ca}^{2+}$ solution. This result was confirmed in three more cells. From the experiments with low as well as with high external $\mathrm{Ca}^{2+}$, we conclude that this ion is directly involved in the mechanism of the channel closure by APB.

Blockage of nonselective cation channels by divalent cations has been used as a means to characterize such channels. To a first approximation, divalent cations and their action at the NMDA-gated channel can be categorized as $\mathrm{Mg}^{2+}-$ like $\left(\mathrm{Co}^{2+}\right.$, $\mathrm{Mn}^{2+}$ ) or $\mathrm{Ca}^{2+}-$ like $\left(\mathrm{Ba}^{2+}, \mathrm{Cd}^{2+}\right.$; Ascher and Nowak, 1988). Comparable results have been reported for the cGMP-gated channels of the photoreceptors, which are partially blocked by $\mathrm{Mg}^{2+}$ and $\mathrm{Ca}^{2+}$ in the external medium (Haynes et al., 1986; Matthews, 1986; Matthews and Watanabe, 1987).

Figure 8 shows that it is not only high extracellular $\mathrm{Ca}^{2+}$ concentration that closes the channels in the absence of APB. High concentrations ( $25 \mathrm{~mm}$ ) of $\mathrm{Co}^{2+}$ or $\mathrm{Cd}^{2+}$ (not shown) were tested in two and three cells, respectively, and also blocked the channels (Fig. 8A). A concentration of $2 \mathrm{mM} \mathrm{La}^{3+}$ was tested in four cells and blocked the channels (Fig. $8 B$ ). Results with $\mathrm{Ba}^{2+}$ ( $25 \mathrm{mM}$ ) and $\mathrm{Sr}^{2+}(25 \mathrm{mM})$ were obtained for two cells, and both ions blocked the channels in onc ccll. In contrast, $\mathrm{Mg}^{2+}$ at a concentration of $25 \mathrm{~mm}$, tested on two cells (Fig. 8C), was not able to block the channels. These results are preliminary because 


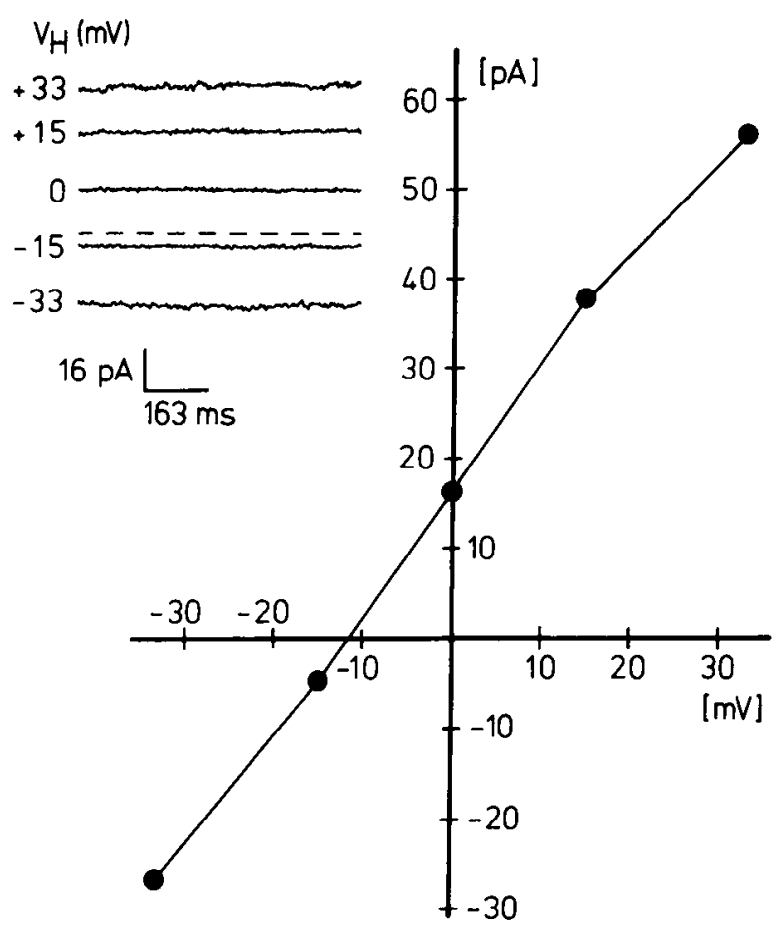

Figure 5. Estimate of the reversal potential of the APB-sensitive tonic inward current. An isolated rod bipolar cell was voltage clamped initially at $V_{I}=-33 \mathrm{mV}$. The cell showed a tonic inward current of $27 \mathrm{pA}$. The holding potential was changed from $-33 \mathrm{mV}$ to $-15,0,+15$, and $+33 \mathrm{mV}$ (inset). The broken line in the inset indicates 0 current level. The current amplitudes were plotted against the holding potentials ( $a b$ scissa) in the graph. On the ordinate, outward currents were plotted as positive, and inward currents as negative. The reversal potential of the tonic current is estimated as $-11.5 \mathrm{mV}$. The seal resistance was measured just after the gigaseal formation and was $20 \mathrm{G} \Omega$. The leak currents were not subtracted. A $\mathrm{CsCl}$ patch pipette was used to block voltageactivated potassium currents. The patch pipette contained $149 \mathrm{mM} \mathrm{CsCl}$, $10 \mathrm{~mm}$ HEPES-KOH at $\mathrm{pH} 7.2$, and nystatin $(200 \mu \mathrm{g} / \mathrm{ml})$. The bath solution contained (in mM) $137 \mathrm{NaCl}, 5 \mathrm{KCl}, 2.5 \mathrm{CaCl}_{2}, 1 \mathrm{MgCl}_{2}, 22.2$ glucose, and 10 HEPES-NaOH, pH 7.2.

of the small sample of cells and the possibility of nonspecific effects on the membrane. They suggest, however, that the APBsensitive channel could be blocked by binding of polyvalent metal ions to the channel.

It is known that, in the mudpuppy (Slaughter and Miller, 1981 ) and in the fish retina (Shiells et al., 1981), APB responses can be evoked in the presence of 2-3 $\mathrm{mM} \mathrm{Co}^{2+}$. Cobalt at $2 \mathrm{~mm}$ concentration had no effect on the APB responses of isolated rod bipolar cells in the present study.

\section{Is the APB-sensitive current the result of $\mathrm{Na}^{+} / \mathrm{Ca}^{2+}$ exchanger?}

We tested the idea that the inward current is caused by an $\mathrm{Na}^{+} /$ $\mathrm{Ca}^{2+}$ exchanger, which transports three $\mathrm{Na}^{+}$ions into the cell and one $\mathrm{Ca}^{2+}$ ion out of the cell (reviewed by Reeves and Philipson, 1989; Reeves, 1990). Such an exchanger has been described in horizontal cells (Yasui, 1987) and in rod outer segments (Yau and Nakatani, 1984b). Recent evidence suggests that $\mathrm{Na}^{\prime} / \mathrm{Ca}^{21}$ exchange in rod outer segments is coupled to $\mathrm{K}^{+}$movements with a suggested stoichiometry of $4 \mathrm{Na}^{+}$per $1 \mathrm{Ca}^{2+}+1 \mathrm{~K}^{+}$ (Cervetto et al., 1989; Schnetkamp et al., 1989). Replacement of external $\mathrm{Na}^{+}$by $\mathrm{Li}^{+}$or $\mathrm{K}^{+}$has been shown to block the exchanger efficiently (Yau and Nakatani, 1984b; Reeves and Philipson, 1989).

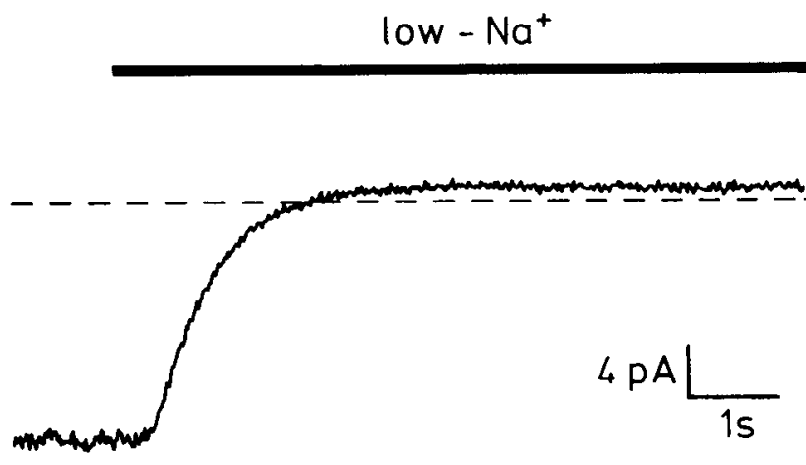

Figure 6. Reversal of an APB-sensitive tonic inward current by reducing the extracellular $\left[\mathrm{Na}^{+}\right]$. An isolated rod bipolar cell was voltage clamped at $V_{H}=-33 \mathrm{mV}$. The cell showed a tonic inward current of $18 \mathrm{pA}$. APB decreased the tonic current; after APB application, the current returned to the predrug level (not illustrated). A low- $\mathrm{Na}^{+}$solution (137 mM NaCl was replaced with equimolar choline chloride in the bath solution) applied through the puffer pipette caused a current reversal. The bath solution contained (in $\mathrm{mM}$ ) $137 \mathrm{NaCl}, 5 \mathrm{KCl}, 2.5$ $\mathrm{CaCl}_{2}, 1 \mathrm{MgCl}_{2}, 22.2$ glucose, and 10 HEPES-NaOH, pH 7.2. The patch

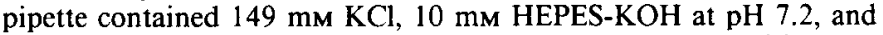
nystatin $(200 \mu \mathrm{g} / \mathrm{ml})$. Broken line, 0 current level; horizontal har, application of low- $\mathrm{Na}^{+}$solution.

In the puffer pipette, $137 \mathrm{~mm} \mathrm{Na}^{+}$was replaced by $137 \mathrm{~mm}$ $\mathrm{Li}^{+}$, and this solution was applied to the cells. No change of the tonic inward current was observed (three cells). To test the blockage by $\mathrm{K}^{+}$ions, the puffer pipette was filled with $137 \mathrm{~mm}$ $\mathrm{Na}^{+}$and $30 \mathrm{~mm} \mathrm{~K}{ }^{+}$, which was applied to the cell. The inward current was slightly increased. As a final experiment for the possibility of an $\mathrm{Na}^{+} / \mathrm{Ca}^{2+}$ exchange, the blocking agent amiloride $\left(10^{-4} \mathrm{M}\right)$ was tested. The inward current could not be blocked (three cells). All three experiments suggest that $\mathrm{Na}^{+}$ $\mathrm{Ca}^{2+}$ exchange is not the major source of the APB-sensitive current.

\section{Noninvolvement of $P K C$ in the $A P B$ response}

Rod bipolar cells are characterized by their abundance of PKC (Fig. 1; Negishi et al., 1988; Greferath et al., 1990; Karschin and Wässle, 1990). We examined the role of this enzyme in the $A P B$ response, and based on the results, it is unlikely that the response to $\mathrm{APB}$ was caused by the phosphorylation of a channel molecule by PKC.

The PKC activator PDBu (Castagna et al., 1982) did not decrease the amplitudes of the APB-sensitive currents $(n=15)$. $\mathrm{PDBu}(1-20 \mu \mathrm{M})$ was applied extracellularly with a puffer pipette for 14.4-72 sec. Conversely, the PKC inhibitor H-7 (Hidaka et al., 1984) did not prevent the APB responses $(n=8)$. H-7 (500 $\mu \mathrm{M})$ was coapplied with $500 \mu \mathrm{M}$ APB for $7.2 \mathrm{sec}$. These results indicate that neither $\mathrm{PDBu}$ nor $\mathrm{H}-7$ alter the channel activity, at least in the above experimental conditions.

\section{Modulation of the APB-sensitive inward current by internal calcium}

Intracellular calcium is involved in many signal transduction pathways that regulate ion channels (Marty et al., 1984; Inoue et al., 1986; Taleb et al., 1987; Brown and Higashida, 1988; Matthews et al., 1989a,b; Oosawa and Yamagishi, 1989; Inoue and Isenberg, 1990; Reiser et al., 1990). The pores formed by nystatin are not permeable to divalent cations (Horn and Marty, 1988); hence, intracellular $\mathrm{Ca}^{2+}$ cannot be buffered or increased through the electrode. Instead, we used a calcium ionophore 


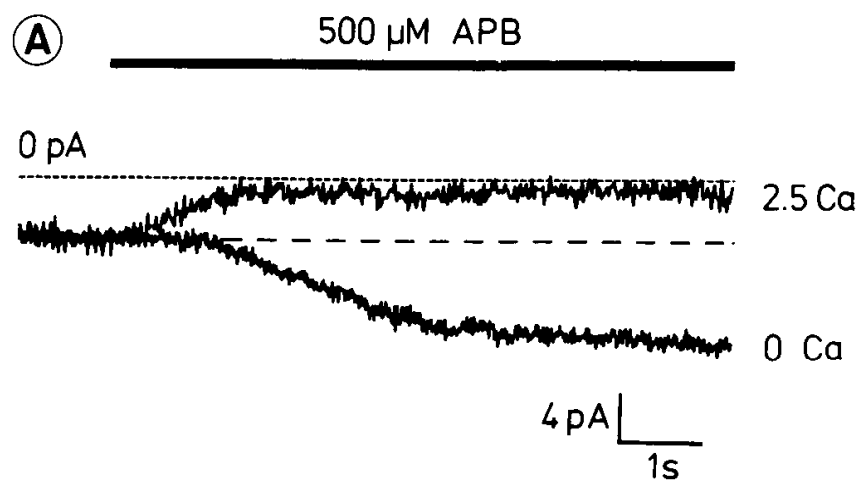

(B)

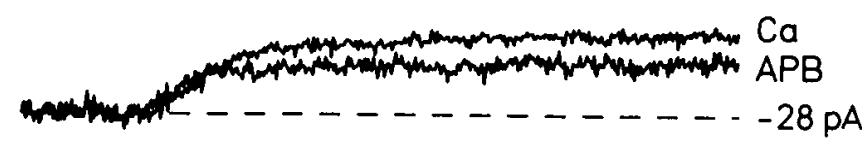

$4 \mathrm{pA} \frac{}{1 \mathrm{~s}}$

Figure 7. The effects of changing extracellular $\left[\mathrm{Ca}^{2+}\right]$ on the APBsensitive tonic inward currents in two isolated rod bipolar cells ( $A$ and $B$ ). The cells were voltage clamped at $V_{H}=-33 \mathrm{mV}$. $A$, Lowering $\left[\mathrm{Ca}^{2+}\right.$. When APB (500 $\mu \mathrm{M}$ in the puffer pipette) was coapplied with nominally $\mathrm{Ca}^{2+}$-free solution $\left(2.5 \mathrm{mM} \mathrm{CaCl}_{2}\right.$ was replaced with equimolar $\mathrm{MgCl}_{2}$ in the bath solution; no EGTA was added), the amplitude of the tonic inward current was increased (indicated by $\mathrm{O} \mathrm{Ca}$ ). The current was decreased by the same concentration of APB when applied in normal bath solution (containing $2.5 \mathrm{~mm} \mathrm{Ca}^{2+}$; indicated by $2.5 \mathrm{Ca}$ ). Dotted line, 0 current level; dashed line, predrug level $(-5.5 \mathrm{pA}) . B$, Increasing $\left[\mathrm{Ca}^{2+}\right]$. When high $\mathrm{Ca}^{2+}(25 \mathrm{~mm}$ in the puffer pipette) was applied to another rod bipolar cell, the amplitude of the tonic inward current was decreased even in the absence of APB (indicated by $\mathrm{Ca}$ ). The current was also decreased by APB ( $500 \mu \mathrm{M}$ in the puffer pipette in normal bath solution; indicated by $A P B)$. Broken line, predrug level $(-28 \mathrm{pA})$; horizontal bars, duration of test drug application. The patch pipcttcs in $A$ and $B$ contained $149 \mathrm{~mm} \mathrm{CsCl}, 10 \mathrm{~mm}$ IIEPES-KOH at $\mathrm{pH} 7.2$, and nystatin $(200 \mu \mathrm{g} / \mathrm{ml})$. The bath solution in $A$ and $B$ contained (in $\mathrm{mM}$ ) $137 \mathrm{NaCl}, 5 \mathrm{KCl}, 2.5 \mathrm{CaCl}_{2}, 1 \mathrm{MgCl}_{2}, 22.2$ glucose, and 10 HEPES-NaOH, pH 7.2.

(A23187) in the bathing medium to modulate $\mathrm{Ca}^{2+}$ entry into the cell. The $\mathrm{Ca}^{2+}$ ionophore $(1 \mu \mathrm{M})$ was applied extracellularly by a puffer pipette; the vehicle alone $(0.1 \%$ methanol) had no effect.

In cells that initially showed very small inward currents $(\approx 1$ $\mathrm{pA}$ at $V_{H}=-33 \mathrm{mV}$ ) and that lacked APB responses, rather large inward currents appeared abruptly upon application of the $\mathrm{Ca}^{2+}$ ionophore. When APB was applied, these currents were reduced but never completely blocked. It is very likely that, in addition to APB-sensitive currents, APB-insensitive inward currents were activated by the ionophore or by the increase in intracellular $\mathrm{Ca}^{2+}$ concentration. However, the appearance of an APB-sensitive current in cells lacking such a current before the $\mathrm{Ca}^{2+}$ ionophore was applied suggests that the intracellular $\mathrm{Ca}^{2+}$ concentration plays an important role in keeping these channels in an open state.
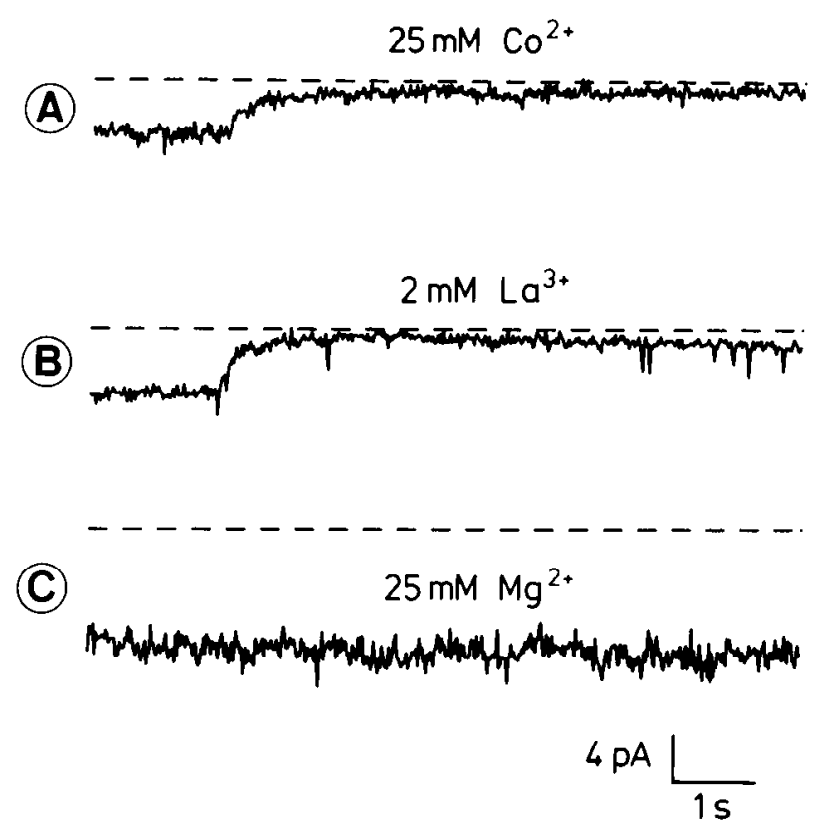

Figure 8. The effects of polyvalent metal ions on APB-sensitive tonic inward currents in three isolated rod bipolar cells $(A-C)$. The cells were voltage clamped at $V_{H}=-33 \mathrm{mV}$, and the tonic inward currents were reduced by $500 \mu \mathrm{M}$ APB (not illustrated). The tonic inward currents were blocked by $25 \mathrm{~mm} \mathrm{Co}{ }^{2+}(A)$ and $2 \mathrm{mM} \mathrm{La}^{3+}(B)$, but were not changed by $25 \mathrm{~mm} \mathrm{Mg}{ }^{2+}(C)$. Drug concentrations refer to solutions in the puffer pipettes. Broken lines, 0 current levels; horizontal bars, duration of application of metal ions. The patch pipettes in $A-C$ contained $149 \mathrm{~mm} \mathrm{CsCl}, 10 \mathrm{~mm}$ HEPES-KOH at pH 7.2, and nystatin $(200 \mu \mathrm{g} /$ $\mathrm{ml}$ ). The bath solution in A-C contained (in $\mathrm{mM}$ ) $137 \mathrm{NaCl}, 5 \mathrm{KCl}, 2.5$ $\mathrm{CaCl}_{2}, 1 \mathrm{MgCl}_{2}, 22.2$ glucose, and 10 HEPES-NaOH, pH 7.2. Calibration applies to all three traces.

\section{Discussion}

$O N$-bipolar cell light responses and $A P B$ action

When APB was described by Slaughter and Miller (1981) as a specific agonist that mimics the photoreceptor transmitter action in ON-bipolar cells, a very powerful pharmacological tool became available. A specific blockade of the ON-pathway by APB was later confirmed in the rabbit retina (Massey et al., 1983; Bloomfield and Dowling, 1985), in the cat retina (Bolz et al., 1984), and in the monkey retina (Knapp and Schiller, 1984). The methods applied included intracellular recordings, extracellular recordings, electroretinogram (ERG) measurements, and behavioral tests. All these experiments suggest that the $\mathrm{ON}$ pathway in most vertebrate retinas is blocked by APB.

A single morphological type of bipolar cell contacts the rods of the mammalian retina. This bipolar ccll makes invaginating synapses into the rod spherules, and its axon ends in the inner plexiform layer close to the ganglion cells. Both of these are anatomical signs that the cell is an ON-bipolar cell. Intracellular recordings in rabbit showed that rod bipolar cells are depolarized at light onset, whereas in the cat, hyperpolarizing responses have been reported. When APB was applied to the dark-adapted cat (Müller et al., 1988), monkey (Dolan and Schiller, 1989), or rabbit retina ( $R$. J. Jensen, personal communication), all light responses of ganglion cells were blocked, suggesting that all rod bipolar cells have APB-sensitive channels.

Despite the wealth of data showing that APB blocks light 
responses of ON-bipolar cells, the exact mode of action is still unclear. In both the mudpuppy (Slaughter and Miller, 1981, 1985 ) and the dogfish (Shiells et al., 1981) retina, APB blocks ON-bipolar cell light responses and hyperpolarizes the cells by a channel-closure mechanism. In goldfish retina, APB also hyperpolarizes ON-bipolar cells by closing channels; however, the cells had additional excitatory amino acid receptors, which responded to glutamate with a conductance increase (Nawy and Copenhagen, 1987, 1990). This would support the notion of Saito (1987) that ON-bipolar cells respond to the photoreceptor transmitter with both channel-opening and channel-closure events.

Patch-clamp recordings from retinal slices or from dissociated bipolar cells have also suggested two possible mechanisms. Attwell et al. (1987) found that depolarizing bipolar cells of tiger salamander retina (either as slices or dissociated) responded to glutamate with a channel-closure mechanism. Hirano et al. (1988) stated that, depending on the mode of dissociation, both channel openings and channel closures can be elicited by application of APB. Karschin and Wässle (1990) found that APB closed channels in a minority of isolated rod bipolar cells, while in the majority of cells, channel openings were observed.

In a recent study, Nawy and Jahr (1990b) demonstrated in a slice preparation of the tiger salamander retina that glutamate hyperpolarizes $\mathrm{ON}$-bipolar cells by decreasing a nonspecific cation conductance. They also reported a washout of the glutamate responses and suggested that this might be the reason for the difficulty in finding glutamate responses in isolated ON-bipolar cells (Lasater et al., 1984; Attwell et al., 1987) as well as in ONbipolar cells of a retinal slice preparation (Maguire et al., 1989).

\section{$A P B$ responses of isolated rod bipolar cells using the nystatin method}

Rod bipolar cells and some amacrine cells of mammalian retinas are labeled by immunocytochemistry with antibodies against PKC (Negishi et al., 1988; Greferath et al., 1990; Karschin and Wässle, 1990). All intact bipolar cells in the dissociates also express PKC immunoreactivity; hence, they are rod bipolar cells (Karschin and Wässle, 1990). The cells are very small (diameter, $7 \mu \mathrm{m}$ ), and most of the cell body is occupied by the nucleus. Hence, as demonstrated in Figure $2 C$, the cells are perfused rapidly during conventional whole-cell patch-clamp recordings. Washout of second-messenger systems and disturbance of the internal $\mathrm{Ca}^{2+}$ concentration might be reasons why only a small fraction of the cells in the experiments of Karschin and Wässle (1990) showed the correct glutamate responses.

In the present experiments, the perforated-patch method of Horn and Marty (1988) was applied. The pores opened by nystatin are permeable for monovalent cations and anions; it is very unlikely that $\mathrm{Ca}^{2+}$ or internal second-messenger systems are washed out. Under these conditions, we observed a tonic inward current in more than half of the rod bipolar cells, and this current was decreased by APB, which probably closed channels. The channels are nonselective cation channels, and at $V_{H}$ $=-33 \mathrm{mV}, \mathrm{Na}^{+}$appears to be the main charge carrier giving rise to an inward current.

\section{Analysis of the APB-sensitive channel}

Despite the use of nystatin in the patch electrode, for several reasons it was very difficult to investigate thoroughly the APBsensitive inward current. One reason for this shortcoming is the small size of the rod bipolar cells, from which stable recordings were obtained for a maximum of $20 \mathrm{~min}$. Only half of the cells showed an inward current of distinct size. It is possible that the channels are concentrated on the dendritic tips where they penetrate the rod spherules. The fine dendrites could be lost during dissociation; only a limited number of channels would then remain intact. Membrane patches pulled out from the soma never contained APB-gated channels; therefore, single-channel events could not be studied.

Despite these limitations, some important information can be gained from the present experiments. It was obvious that $\mathrm{Ca}^{2+}$ played an important role in gating the channel. The experiment with the $\mathrm{Ca}^{2+}$ ionophore, which induces $A P B$-sensitive currents, makes it likely that a minimum internal $\mathrm{Ca}^{2+}$ concentration is necessary to keep the channels open. It is well known that the internal $\mathrm{Ca}^{2+}$ concentration plays an important role in channels regulated by transmitters through second-messenger systems. The failure of Karschin and Wässle (1990) to detect this current in most of the cells recorded might have been caused by a washout of internal $\mathrm{Ca}^{2+}$ and the low-Ca ${ }^{2+}$ buffering of $10^{-8}$ or $2 \times 10^{-7} \mathrm{M}$ with EGTA that was used in their experiment. We also noticed that external $\mathrm{Ca}^{2+}$ had an important influence on the channels. High external $\mathrm{Ca}^{2+}(25 \mathrm{~mm})$ could close the channel even in the absence of APB. In contrast, when the outside concentration of $\mathrm{Ca}^{2+}$ was low, APB could not close the channel, but instead caused further opening. When the external concentration of $\mathrm{Ca}^{2+}$ was reduced in the absence of APB, the tonic inward current increased slowly. This is difficult to understand and suggests some kind of cooperativity between APB and the outside $\mathrm{Ca}^{2+}$ in closing the channels. It is also possible that removal of $\mathrm{Ca}^{2+}$ from the bathing solution alters the gating properties of other channels. It has been described that $\mathrm{Ca}^{2+}$ is essential for a proper function of voltage-dependent $\mathrm{K}^{+}$channels and that low $\mathrm{Ca}^{2+}$ induces a large, nonselective "leak" conductance (Armstrong and Miller, 1990).

Attwell et al. (1987) recorded glutamate responses in depolarizing bipolar cells of the axolotl retina and analyzed the current noise. In agreement with their results, in the present study we found that APB induces a conductance decrease and a reduction in noise (Figs. 3, 4). As discussed by Attwell et al. (1987), this result immediately rules out the simplest model of glutamate action, a scheme in which the transmitter binds to a receptor associated with the open channel and the channel then closes. In such a model, the noise variance should increase by the action of the transmitter. Attwell et al. (1987) also showed that the channel's open probability has to be less than 0.5 in the absence of APB or glutamate and proposed a simple alternative scheme:

$$
\begin{array}{ccccc}
R^{*} & \stackrel{\alpha}{c} & + & & \\
& \stackrel{+}{*} & R & k_{1} & \\
\text { open } & & \text { closed } & & \text { closed }
\end{array} .
$$

In the absence of transmitter $(T)$, the receptor-channel complex can exist in two states, open $\left(R^{*}\right)$ and closed $(R)$, and the fraction of channels that are open depends on $\beta /(\alpha+\beta)$. If $\beta<\alpha$, the open probability is $<0.5$. The transmitter binds to the closed state $(R)$. If $\alpha$ and $\beta$ were influenced by the external and internal $\mathrm{Ca}^{2+}$ concentration, such a model is compatible with the results of the present article.

The $\mathrm{Ca}^{2+}$ effects on the inward current are reminiscent of an 
$\mathrm{Na}^{+} / \mathrm{Ca}^{2+}$ exchange mechanism, but we do not believe such a mechanism could explain our results. An $\mathrm{Na}^{+} / \mathrm{Ca}^{2+}$ exchanger has been described in rod outer segments (Yau and Nakatani, 1984b) and in horizontal cells (Yasui, 1987), and it would produce a net inward current similar to the one described in the present experiments. However, replacing external $\mathrm{Na}^{+}$by $\mathrm{Li}^{+}$ should block the exchanger. It would also be blocked by high external $\mathrm{K}^{+}$and by amiloride derivatives. All three tests were performed, and none abolished the APB-sensitive inward current. These results, as well as the decrease in current noise (Fig. $3 B, D)$, suggest that a channel is indeed gated by APB.

It has been reported for isolated horizontal cells of the fish retina (Ishida and Neyton, 1985) that inward currents evoked by kainate were inhibited by $\mathrm{L}$-glutamate or quisqualate. Although the perfusion chamber in the present experiments was perfused continuously, there might be a spontaneous release of glutamate from the many thousands of neurons in the chamber. This background concentration of glutamate could keep channels in an open state, and application of APB could, as in the experiments of Ishida and Neyton (1985), inhibit such conductances. To rule out this possibility, puffer pipettes were filled with fresh bathing solution, which was ejected onto the cells. It was found to have no effect, which rules out the possibility that a background concentration of glutamate might keep channels in an open state.

The staining of rod bipolar cells with antibodies against PKC would suggest the existence of a second-messenger system involving inositol triphosphate hydrolysis. However, we found that neither PKC activation by PDBu (Castagna et al., 1982) nor PKC inhibition by H-7 (Hidaka et al., 1984) had any effect on the APB-sensitive currents.

After the present study was completed, Nawy and Jahr (1990a) reported that depolarizing bipolar cells of the tiger salamander retina have a membrane conductance similar to that of rod outer segments. The glutamate (APB) receptor seems to close ion channels by increasing the rate of cGMP hydrolysis via a G-protein-mediated process that is strikingly similar to light transduction in photoreceptors. Whether such a second-messenger system is also present in mammalian rod bipolar cells has yet to be tested. Many of the results presented here are compatible with such a mechanism.

\section{Light responses of rod bipolar cells and the $b$-wave of the $E R G$}

How can a "channel-closing" mechanism produce the light responses of rod bipolar cells? Suppose the cell is initially voltage clamped at $-50 \mathrm{mV}$, and the clamp is then released. In the absence of photoreceptor transmitter (i.e., in the light), the APBgated channels are open, and there is more $\mathrm{Na}^{+}$influx than there is $\mathrm{K}^{\prime}$ efflux through these channels. Hence, the cell will be depolarized. However, at a voltage of about $-30 \mathrm{mV}$, voltagedependent $\mathrm{K}^{+}$channels are activated, and $\mathrm{K}^{+}$efflux is increased (Kaneko et al., 1989; Karschin and Wässle, 1990; Yeh et al., 1990). This will keep the membrane depolarized at a voltage at which $\mathrm{Na}^{+}$influx through APB-sensitive channels balances the total $\mathrm{K}^{+}$efflux. When APB or the rod transmitter bind (in darkness), the APB-sensitive channel closes, and $\mathrm{Na}^{+}$influx stops. Due to the continued $\mathrm{K}^{+}$efflux through the voltage-gated $\mathrm{K}^{+}$ channcls, the cell will be hyperpolarized.

It is generally assumed that the b-wave of the ERG reflects an increase of the extracellular $\mathrm{K}^{+}$due to the depolarization of ON-bipolar cells by the light stimulus (Miller and Dowling, 1970; Newman, 1988; Stockton and Slaughter, 1989). It is in- teresting to compare the "channel-closing model" and the "channel-opening model" of ON-bipolar responses with respect to the $\mathrm{K}^{+}$fluxes they would producc. In the "channel-opening model," the photoreceptor transmitter released in the darkness would open channels for $\mathrm{K}^{+}$, and the $\mathrm{K}^{+}$efflux would keep the cell hyperpolarized. Illumination would stop the release of photoreceptor transmitter, the transmitter-activated channels for $\mathrm{K}^{+}$would close, and the efflux of $\mathrm{K}^{+}$would decrease. Thus, in this model, extracellular $\mathrm{K}^{+}$would be decreased by light. In the "channel-closing model," as described above, in darkness the photoreceptor transmitter keeps nonselective cation channels closed, and the bipolar cells are hyperpolarized. Illumination causes an opening of cation channels, $\mathrm{Na}^{+}$enters the cells, and a depolarization level is reached, at which $\mathrm{Na}^{+}$influx and $\mathrm{K}^{+}$ efflux counterbalance one another. In this model, extracellular $\mathrm{K}^{+}$is increased by light.

In the dark-adapted mammalian retinas, a strong b-wave is measured in ERG recordings (Gouras and Evers, 1985). This b-wave is blocked by APB (Müller et al., 1988), which is additional evidence that rod bipolar cells might respond to the photoreceptor transmitter through a channel-closure mechanism.

\section{References}

Almers W, McCleskey EW, Palade PT (1984) A non-selective cation conductance in frog muscle membrane blocked by micromolar external calcium ions. J Physiol (Lond) 353:565-583.

Armstrong CM, Miller C (1990) Do voltage-dependent $\mathrm{K}^{+}$channels require $\mathrm{Ca}^{2+}$ ? A critical test employing a heterologous expression system. Proc Natl Acad Sci USA 87:7579-7582.

Ascher P, Nowak L (1988) The role of divalent cations in the $N$-methyl-D-aspartate responses of mouse central neurones in culture. $J$ Physiol (Lond) 399:247-266.

Attwell D, Mobbs P, Tessier-Lavigne M, Wilson M (1987) Neurotransmitter induced currents in retinal bipolar cells of the axolotl, Ambystoma mexicanum. J Physiol (Lond) 387:125-161.

$\Lambda$ youb GS, Korenbrot JI, Copenhagen DR (1989) Release of endogenous glutamate from isolated cone photoreceptors of the lizard. Neurosci Res [Suppl] 10:S47-S56.

Bloomfield SA, Dowling JE (1985) Roles of aspartate and glutamate in synaptic transmission in rabbit retina. I. Outer plexiform layer. $J$ Neurophysiol 53:699-713.

Bolz J, Wässle H, Thier P (1984) Pharmacological modulation of ONand OFF-ganglion cells in the cat retina. Neuroscience 12:875-885.

Brown DA, Higashida $H$ (1988) Inositol 1,4,5-trisphosphate and diacylglycerol mimic bradykinin effects on mouse neuroblastoma $\times$ rat glioma hybrid cells. J Physiol (Lond) 397:185-207.

Castagna M, Takai Y, Kaibuchi K, Sano K, Kikkawa U, Nishizuka Y (1982) Direct activation of calcium-activated, phospholipid-dependent protein kinase by tumor-promoting phorbol esters. J Biol Chem 257:7847-7851.

Cervetto L, MacNichol EF (1972) Inactivation of horizontal cells in turtle retina by glutamate and aspartate. Science 178:767-768.

Cervetto L, Lagnado L, Perry RJ, Robinson DW, McNaughton PA (1989) Extrusion of calcium from rod outer segments is driven by both sodium and potassium gradients. Nature 337:740-743.

Copenhagen DR, Jahr CE (1989) Release of endogeneous excitatory amino acids from turtle photoreceptors. Nature 341:536-539.

Dacheux RF, Raviola E (1986) The rod pathway in the rabbit retina a depolarizing bipolar and amacrine cell. J Neurosci 6:331-345.

Daw NW, Jensen RJ, Brunken WJ (1990) Rod pathways in mammalian retinae. Trends Neurosci 13:110-115.

Dolan RP, Schiller PH (1989) Evidence for only depolarizing rod bipolar cells in the primate retina. Vis Neurosci 2:421-424.

Fenwick, EM, Marty A, Neher E (1982) A patch-clamp study of bovine chromaffin cells and of their sensitivity to acetylcholine. J Physiol (Lond) 331:577-597.

Franke C, Hatt H, Dudel J (1987) Liquid filament switch for ultrafast exchanges of solutions at excised patches of synaptic membrane of crayfish muscle. Neurosci Lett 77:199-204. 
Gouras P, Evers HU (1985) The neurocircuitry of primate retina. In: Neurocircuitry of the retina, a Cajal memorial (Gallego A, Gouras P, eds), pp. 233-244. Amsterdam: Elsevier.

Greferath U, Grünert U, Wässle H (1990) Rod bipolar cells in the mammalian retina show protein kinase C-like immunoreactivity. J Comp Neurol 301:433-442.

Haynes LW, Kay AR, Yau KW (1986) Single cyclic GMP-activated channel activity in excised patches of rod outer segment membrane. Nature 321:66-70.

Hidaka H, Inagaki M, Kawamoto S, Sasaki Y (1984) Isoquinolinesulfonamides, novel and potent inhibitors of cyclic nucleotide dependent protein kinase and protein kinase C. Biochemistry 23:50365041.

Hirano AA, Hirsch JA, MacLeish PR (1988) Glutamate responses in solitary bipolar cells from salamander retina. Soc Neurosci Abstr 14: 396.2 .

Horn R, Marty A (1988) Muscarinic activation of ionic currents measured by a new whole-cell recording method. J Gen Physiol 92:145159.

Inoue M, Oomura Y, Yakushiji T, Akaike N (1986) Intracellular calcium ions decrease the affinity of the GABA receptor. Nature 324: 156-158.

Inoue R, Isenberg G (1990) Intracellular calcium ions modulate acctylcholine-induced inward current in guinea-pig ileum. J Physiol (Lond) 424:73-92.

Ishida AT, Neyton J (1985) Quisqualate and L-glutamate inhibit retinal horizontal-cell responses to kainate. Proc Natl Acad Sci USA 82: $1837-1841$

Kaneko A (1970) Physiological and morphological identification of horizontal, bipolar, and amacrine cells in goldfish retina. J Physiol (Lond) 207:623-633.

Kaneko A, Tachibana M (1985) A voltage-clamp analysis of membrane currents in solitary bipolar cells dissociated from Carassius auratus. J Physiol (Lond) 358:131-152.

Kaneko A, Pinto LH, Tachibana M (1989) Transient calcium current of retinal bipolar cells of the mouse. J Physiol (Lond) 410:613-629.

Karschin A, Wässle H (1990) Voltage- and transmitter-gated currents in isolated rod bipolar cells of rat retina. J Neurophysiol 63:860-876.

Knapp AG, Schiller PH (1984) The contribution of on-bipolar cells to the electroretinogram of rabbits and monkey. Vision Res 24:18411846.

Kolb H, Nelson R (1983) Rod pathways in the retina of the cat. Vision Res 23:301-312.

Kondo H, Toyoda J-I (1980) Dual effect of glutamate and aspartate on the on-center hipolar cell in the carp retina. Brain Res 199:240243.

Kurachi Y, Asano Y, Takikawa R, Sugimoto T (1989) Cardiac Ca current does not run down and is very sensitive to isoprenaline in the nystatin-method of whole cell recording. Naunyn Schmiedebergs Arch Pharmacol 340:219-222.

Lasater EM (1988) Membrane currents of retinal bipolar cells in culture. J Neurophysiol 60:1460-1480.

Lasater EM, Dowling JE, Ripps H (1984) Pharmacological properties of isolated horizontal and bipolar cells from the skate retina. J Neurosci 4:1966-1975.

Maguire G, Lukasiewicz P, Werblin F (1989) Amacrine cell interactions underlying the response to change in the tiger salamander retina. J Neurosci 9:726-735.

Marc RE, I am DMK (1981) Uptake of aspartate and glutamic acid by photoreceptors in goldfish retina. Proc Natl Acad Sci USA 78: $7185-7189$.

Marty $\Lambda$, Finkelstein A (1975) Pores formed in lipid bilayer membranes by nystatin. J Gen Physiol 65:515-526.

Marty A, Tan YP, Trautmann A (1984) Three types of calcium-dependent channel in rat lacrimal glands. J Physiol (Lond) 357:293325.

Massey SC (1990) Cell types using glutamate as a neurotransmitter in the vertebrate retina. In: Progress in retinal research, Vol 9 (Osborne NN, Chader GJ, eds), pp 399-425. Oxford: Pergamon.

Massey SC, Redburn DA, Crawford MLJ (1983) The effects of 2-amino4-phosphonobutyric acid (APB) on the ERG and ganglion cell discharge of rabbit retina. Vision Res 23:1607-1613.

Matthews G (1986) Comparison of the light-sensitive and cyclic GMPsensitive conductances of the rod photoreceptor: noise characteristics. J Neurosci 6:2521-2526.
Matthews G, Watanabe S1 (1987) Properties of ion channels closed by light and opened by guanosine $3^{\prime}, 5^{\prime}$-cyclic monophosphate in toad retinal rods. J Physiol (Lond) 389:691-715.

Matthews G, Neher E, Penner R (1989a) Second messenger-activated calcium influx in rat peritoneal mast cells. J Physiol (Lond) 418:105130.

Matthews G, Neher E, Penner R (1989b) Chloride conductance activated by external agonists and internal messengers in rat peritoneal mast cells. J Physiol (Lond) 418:131-144.

Mayer ML, Westbrook GL (1987) Permeation and block of $N$-methylD-aspartic acid receptor channels by divalent cations in mouse cultured central neurones. J Physiol (Lond) 394:501-527.

Miller RF, Dowling JE (1970) Intracellular responses of the Müller (glial) cells of the mudpuppy retina: their relation to the b-wave of the electroretinogram. J Neurophysiol 33:323-341.

Müller F, Wässle H, Voigt T (1988) Pharmacological modulation of the rod pathway in the cat retina. J Neurophysiol 59:1657-1672.

Murakami M, Ohtsu K, Ohtsuka T (1972) Effect of chemicals on receptors and horizontal cells in the retina. J Physiol (Lond) 227:899_ 913.

Murakami M, Ohtsuka T, Shimazaki H (1975) Effects of aspartate and glutamate on the bipolar cells in the carp retina. Vision Res 15: $456-458$.

Nawy S, Copenhagen DR (1987) Multiple classes of glutamate receptor on depolarizing bipolar cells in retina. Nature 325:56-58.

Nawy S, Copenhagen DR (1990) Intracellular cesium separates two glutamate conductances in retinal bipolar cells of goldfish. Vision Res 30:967-972.

Nawy S, Jahr CE (1990a) Suppression by glutamate of cGMP-activated conductance in retinal bipolar cells. Nature 346:269-271.

Nawy S, Jahr CE (1990b) Time-dependent reduction of glutamate current in retinal bipolar cells. Neurosci Lett 108:279-283.

Negishi K, Kato S, Teranishi T (1988) Dopamine cells and rod bipolar cells contain protein kinase C-like immunoreactivity in some vertebrate retinas. Neurosci Lett 94:247-252.

Nelson R, Kolb H (1983) Synaptic patterns and response properties of bipolar and ganglion cells in the cat retina. Vision Res 23:11831195 .

Newman EA (1988) Electrophysiology of retinal glial cells. In: Progress in retinal research, Vol 8 (Osborne NN, Chader GJ, eds), pp 153171, Oxford: Pergamon.

Oosawa Y, Yamagishi S (1989) Rat brain glutamate receptors activate chloride channels in Xenopus oocytes coupled by inositol trisphosphate and $\mathrm{Ca}^{2+}$. J Physiol (Lond) 408:223-232.

Perlman I, Normann RA, Chandler JP, Lipetz LE (1990) Effects of calcium ions on L-type horizontal cells in the isolated turtle retina. Vis Neurosci 4:53-62.

Recves JP (1990) Sodium-calcium exchange. In: Intracellular calcium regulation, pp 305-347. New York: Liss.

Reeves JP, Philipson KD (1989) Sodium-calcium exchange activity in plasma membrane vesicles. In: Sodium-calcium exchange (Allen TJA, Noble D, Reuter H, eds), pp 27-53. Oxford: Oxford UP.

Reiser G, Binmöller FJ, Strong PN, Hamprecht B (1990) Activation of a $\mathrm{K}^{+}$conductance by bradykinin and by inositol-1,4,5-trisphosphate in rat glioma cells: involvement of intracellular and extracellular $\mathrm{Ca}^{2+}$. Brain Res 506:205-214.

Saito T (1987) Physiological and morphological differences between on- and off-center bipolar cells in the vertebrate retina. Vision Res $27: 135-142$.

Saito T, Kujiraoka T (1982) Pysiological and morphological identification of two types of ON-center bipolar cells in the carp retina. $J$ Comp Neurol 205:161-170.

Saito T, Kondo H, Toyoda J (1979) Ionic mechanisms of two types of ON-center bipolar cells in the carp retina. I. The responses to central illumination. J Gen Physiol 73:73-90.

Saito T, Kondo H, Toyoda J (1981) Ionic mechanisms of two types of ON-center bipolar cells in the carp retina. II. The responses to annular illumination. J Gen Physiol 78:569-589.

Schnetkamp PPM, Basu DK, Szerencsei RT (1989) $\mathrm{Na}^{+}-\mathrm{Ca}^{2+}$ exchange in bovine rod outer segments requires and transports $\mathrm{K}^{+}$. Am J Physiol 257:153-157.

Shiells RA, Falk G, Naghshineh S (1981) Action of glutamate and aspartate analogues on rod horizontal and bipolar cells. Nature 294: 592-594. 
Slaughter MM, Miller RF (1981) 2-Amino-4-phosphonobutyric acid: a new pharmacological tool for retina research. Science 211:182-185.

Slaughter MM, Miller RF (1983a) The role of excitatory amino acid transmitters in the mudpuppy retina: an analysis with kainic acid and $N$-methyl aspartate. J Neurosci 3:1701-1711.

Slaughter MM, Miller RF (1983b) An excitatory amino acid antagonist blocks cone input to sign-conserving second-order retinal neurons. Science 219:1230-1232.

Slaughter MM, Miller RF (1985) Characterization of an extended glutamate receptor of the on bipolar neuron in the vertebrate retina. J Neurosci 5:224-233.

Stockton RA, Slaughter MM (1989) B-wave of the electroretinogram. A refiection of ON bipolar cell activity. J Gen Physiol 93:101-122.

Suzuki S, Tachibana M, Kaneko A (1990) Effects of glycine and GABA on isolated bipolar cells of the mouse retina. J Physiol (Lond) 421: 645-662.

Tachibana M, Kaneko A (1987) $\gamma$-Aminobutyric acid exerts a local inhibitory action on the axon terminal of bipolar cells: evidence for negative feedback from amacrine cells. Proc Natl Acad Sci USA 84: 3501-3505.

Taleb O, Trouslard J, Demeneix BA, Feltz P, Bossu JL, Dupont JL,
Feltz A (1987) Spontaneous and GABA-evoked chloride channels on pituitary intermediate lobe cells and their internal $\mathrm{Ca}$ requirements. Pfluegers Arch 409:620-631.

Toyoda J (1973) Membrane resistance changes underlying the bipolar cell response in the carp retina. Vision Res 13:283-294.

Werblin FS, Dowling JE (1969) Organization of the retina of the mudpuppy, Necturus maculosus. II. Intracellular recording. J Neurophysiol 32:339-355.

Yamashita M, Wässle H (1991) The reversal potential of GABAinduced currents in rod bipolar cells of the rat retina. Vis Neurosci, in press.

Yasui $\mathrm{S} \mathrm{(1987)} \mathrm{Ca}$ and $\mathrm{Na}$ homeostasis in horizontal cells of the cyprinid fish retina: evidence for $\mathrm{Na}-\mathrm{Ca}$ exchanger and $\mathrm{Na}-\mathrm{K}$ pump. Neurosci Res [Suppl] 6:S133-S146.

Yau KW, Nakatani K (1984a) Cation selectivity of light-sensitive conductance in retinal rods. Nature 309:352-354.

Yau KW, Nakatani K (1984b) Electrogenic Na-Ca exchange in retinal rod outer segments. Nature 311:661-663.

Yeh HH, Lee MB, Cheun JE (1990) Properties of GABA-activated whole-cell currents in bipolar cells of the rat retina. Vis Neurosci 4: 349-357. 